\title{
Intestinal obstruction caused by neoplasms in two cows
}

\author{
Obstrução intestinal causada por neoplasias em duas vacas
}

\author{
Antônio Carlos Lopes Câmara ${ }^{\mathrm{I}}$ Márcio Botelho de Castro ${ }^{\text {II }}$ \\ Eraldo Barbosa Calado ${ }^{I}$ Benito Soto-Blanco ${ }^{\text {III }}$
}

\section{ABSTRACT}

In cattle, abdominal tumors leading to partial or total intestinal obstruction are rare. Here, it is described the clinicopathological findings of two cows with intestinal obstruction by neoplasms. A crossbred cow presented apathy, weight loss, constipation, enophthalmos, ruminal and intestinal hypomotility, and abdominal distension in the right ventral quadrant. Pathological examination revealed bilateral ovarian teratoma. The other case was a cow that in the past 2 years had several episodes of squamous cell carcinoma in the third eyelid and vulva. During the 6 days prior to investigation, clinical signs of constipation and tenesmus were noted. Nodular and friable masses were located in the vulva, right third eyelid and cranially to the right kidney that were identified as poorly differentiated metastatic carcinoma of the adrenal cortex. To our knowledge, these are probably the first reports of ovarian teratoma and adrenal carcinoma causing clinical signs of intestinal obstruction in cattle.
\end{abstract}

- NOTE
Key words: abdominal tumors, intestinal obstruction, metastatic adrenal carcinoma, ovarian teratoma

\section{RESUMO}

Em bovinos, tumores abdominais que levam à obstrução intestinal parcial ou total são raros. Neste relato, descrevemos os achados clínico-patológicos de duas vacas com obstrução intestinal por neoplasias. Uma vaca mestiça apresentava apatia, perda de peso, constipação, enoftalmia, hipomotilidade ruminal e intestinal e distensão abdominal no quadrante ventral direito. $O$ exame patológico revelou teratoma ovariano bilateral. O outro caso foi uma vaca que, nos últimos 2 anos, teve episódios de carcinoma de células escamosas na terceira pálpebra e vulva. Durante 6 dias antes da investigação, foram observados constipação e tenesmo. Massas nodulares e friáveis foram localizados na vulva, terceira pálpebra direita e cranial ao rim direito, que foram identificadas como carcinoma metastático pouco diferenciado do córtex adrenal. Ao nosso conhecimento, estes são os primeiros relatos de teratoma ovariano e carcinoma adrenal causando sinais clínicos de obstrução intestinal em bovinos.

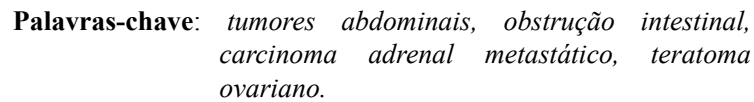

In cattle, mechanical obstructive diseases of the small and large intestines are less common than forestomach and abomasal disorders, but they occur regularly enough to warrant concern in the differential diagnosis of abdominal distention. Intraluminal causes of intestinal obstruction (IO) include trichobezoars, hemorrhagic bowel syndrome, impactions, intussusceptions, and intestinal volvulus. Partial to complete extraluminal IO has been observed in cattle with mesenteric abscesses, fat necrosis, tuberculosis granulomas, intestinal adenocarcinoma, and lymphosarcoma (VAN METRE et al., 2005). Nevertheless, in cattle, abdominal tumors leading to partial or total IO are rare. Here, it is described the clinico-pathological findings of two cows with IO, due to an ovarian teratoma in one and a metastatic adrenal carcinoma in the other.

The first case was of a 6-year-old crossbred cow, weighing $350 \mathrm{~kg}$, with a 15 -day history of apathy, hyporexia, weight loss, constipation, and reduced fecal output. Physical examination revealed that the

\footnotetext{
'Hospital Veterinário, Universidade Federal Rural do Semi-árido (UFERSA), Mossoró, RN, Brasil.

ILLaboratório de Patologia, Universidade de Brasília (UnB), Brasília, DF, Brasil.

IIIDepartamento de Clínica e Cirurgia Veterinárias, Escola de Veterinária, Universidade Federal de Minas Gerais (UFMG), Av. Antônio Carlos, 6627, 3127-501, Belo Horizonte, MG, Brasil. E-mail: benito.blanco@pq.cnpq.br. Corresponding author. Received 11.02.15 Approved 01.15.16 Returned by the author 04.07.16 CR-2015-1488.R
} 
cow was alert, with a good physical condition score, severe dehydration, enophthalmos, tachycardia (100 beats per minute), normal respiratory rate ( 32 breaths per minute), ruminal and intestinal hypomotility, and abdominal distention in the right ventral quadrant. Right flank ballottement revealed highly increased abdominal tension. Rectal palpation showed a hardened multilobular mass in the anatomical location of the uterus. This mass impeded adequate rectal exploration, and during rectal palpation, only scanty feces and mucus were obtained. Hematological analysis revealed normocytic normochromic anemia (MCV: 23\%; hemoglobin: $\left.7.4 \mathrm{~g} \mathrm{dL}^{-1}\right)$ and a slight increase in neutrophil count $\left(5.525 \times 10^{9} \mathrm{~L}^{-1}\right)$. On the basis of the history and physical evaluation findings, this cow was tentatively diagnosed with an ovarian or uterine tumor. During hospitalization, the cow received hydroelectrolyte support and 24h later gave birth to a dead, 7-month-old male fetus with a normal appearance.

Due to the cost benefit analysis and poor prognosis, the owner opted for euthanasia $\left(0.1 \mathrm{mg} \mathrm{kg}^{-1}\right.$ of xylazin and $3 \mathrm{~g}$ of thiopental intravenously followed by an intratecal injection of $60 \mathrm{~mL}$ lydocaine) and a complete post mortem examination was carried out. Necropsy revealed a large abdominal mass in the left ovary with a white-grayish coloration, firm consistency, and smooth surface, measuring $76 \times 41 \mathrm{~cm}$ and weighing $42.8 \mathrm{~kg}$ (Figure 1A). A multinodular white-yellowish colored tumor mass with hemorrhagic areas, measuring $43 \times 22 \mathrm{~cm}$ and weighing $14.4 \mathrm{~kg}$, was found in the right ovary. Upon dissection, both tumor masses were found to have multilobular or cystic aspects, containing yellowish viscous liquid, hemorrhagic foci, and areas with bone and cartilaginous appearance. Microscopic examination revealed that the bilateral masses were ovarian teratomas originating from fibrovascular tissue, with the presence of ovarian tissue with normal morphological appearance nearby. The masses involved multifocal areas composed of adipose tissue, hyaline cartilage, trabecular bone, and numerous cystic structures that were lined with squamous epithelium and filled with horny material (dermoid cysts-like structures) (Figure 1B), or were lined with simple columnar epithelium filled with a proteinaceous material. Light abomasal impaction, absence of feces, and presence of mucus in the large intestines were also evident on necropsy.

The second case was of a 10-year-old Holstein cow weighing $450 \mathrm{~kg}$. During the past 2 years, this cow had several occurrences of tumor-like lesions in the third eyelid and vulva. Each of these tumors was surgically resected and histopathology confirmed as squamous cell carcinomas. During the 6 days prior to death, clinical signs of constipation, tenesmus, and a reduced fecal output were evident. Physical evaluation of the cow revealed slight dehydration, a rumen with increased solid content, moderate constipation, and intestinal hypomotility. Cardiac and respiratory frequencies and rectal temperature were within normal parameters. Nodular and friable masses were located in the vulva and on the right third eyelid. Upon rectal examination, a large firm mass in the right perirenal region and scanty feces with a gross normal appearance were detected. Results of the hematological analysis were within normal reference values. The combined epidemiological and clinical findings permitted the presumptive diagnosis of a metastatic renal carcinoma.

Euthanasia was performed as described earlier. Necropsy revealed a large, friable, and multilobulated mass with irregular, yellowish coloration, and circumscribed hemorrhagic areas, located cranially to the right kidney in the abdominal cavity. The mass measured $16 \times 42 \times 22 \mathrm{~cm}$ and weighed $11.2 \mathrm{~kg}$. It adhered to the descending duodenum and the left uterine horn. Yellowish, multifocal nodules of varying sizes were found in the lungs, spleen, and kidneys, suggesting metastasis and confirmed histopathologically by the presence of tumor emboli in those organs (Figure 1C). Microscopically, the tumor mass was formed by cells with a large, pleomorphic, polyhedral appearance; vesicular nuclei with prominent nucleoli; and eosinophilic cytoplasm, arranged in blocks or strings that were encased in a fibrovascular stroma. The adrenal architecture was completely changed by diffuse infiltration of the tumor cells (Figure 1D), with the presence of large multifocal necrotic areas surrounding hemorrhagic regions. Immunohistochemistry was performed according to GROSSI et al. (2013). The morphological features and immunohistochemical results confirmed the diagnosis of a poorly differentiated metastatic carcinoma of the adrenal cortex.

Both owners reported hyporexia, weight loss, constipation, and reduced fecal output; classical clinical signs of partial IO. To our knowledge, these are the first reports of ovarian teratoma and adrenal carcinoma causing clinical signs of IO in cattle. Several other causes of IO have been reported in cattle, including intraluminal and extraluminal disturbances, but pure intestinal adenocarcinoma and lymphosarcoma have a neoplastic origin (VAN METRE et al., 2005).

Ovarian teratomas in livestock are rare neoplasms of germ cell origin and are most 


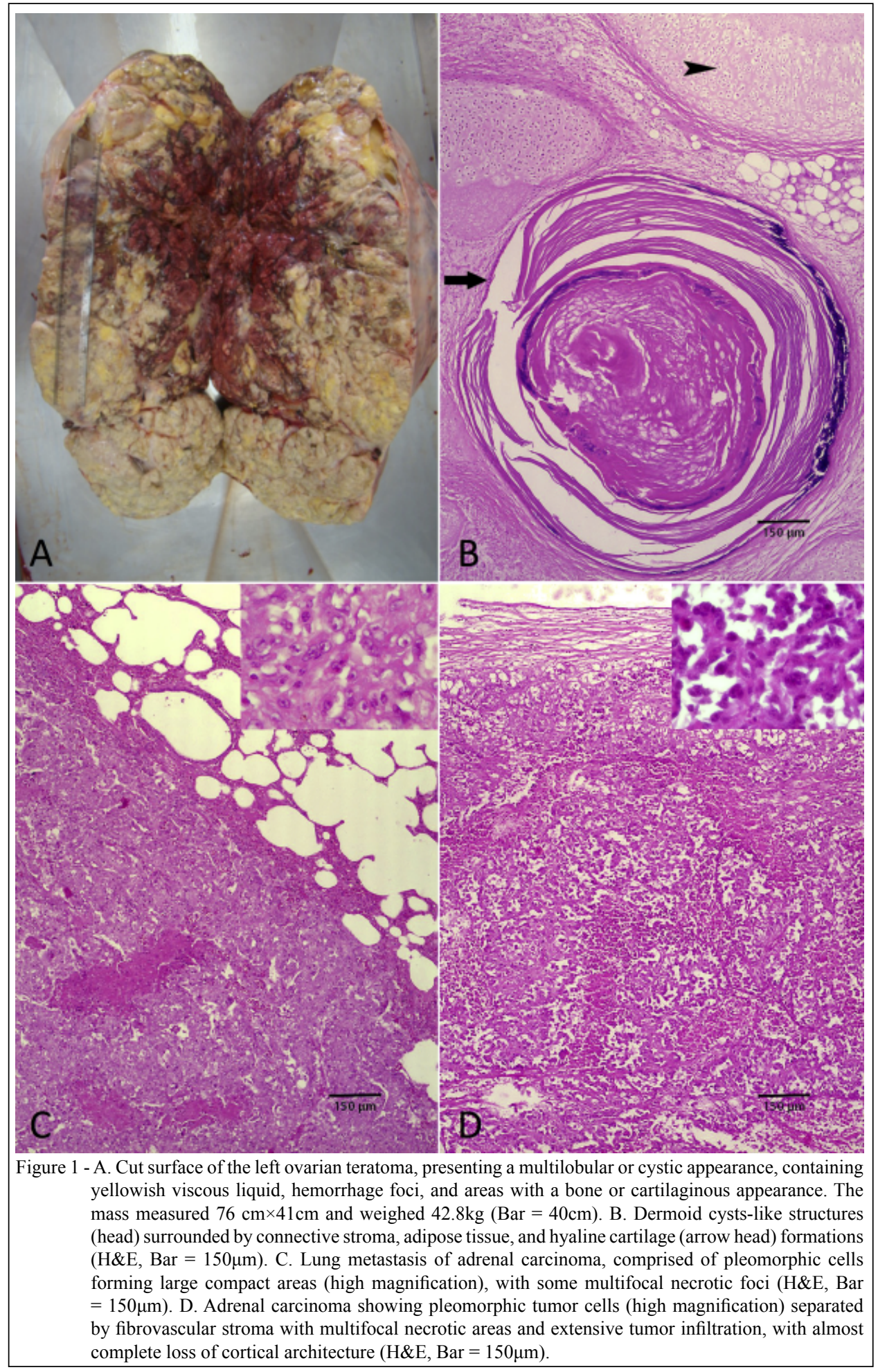

commonly localized in the gonads, both ovaries and testes; although, extragonadal teratomas have been described (SCHLAFER \& MILLER, 2007). Since this neoplasm does not interfere with the reproductive function of females, the diagnosis is an incidental finding upon necropsy or in slaughter houses (MACHADO et al., 2015). In the present case, this was also true, since the cow was gravid and delivered 
a dead fetus that was 7 months old. The large size and weight of the two ovarian masses $(57.2 \mathrm{~kg})$ may have caused mechanical interference with pyloric drainage and intestinal flow, resulting in the necropsy findings of slight abomasal impaction and mucus in the large bowel, since the gravid uterus and the masses may have pushed the abomasum cranially and may have interfered with physiological motility, resulting in a partial obstruction (CÂMARA et al., 2009). The abortion of the fetus was probably due to the severe systemic disturbances caused by the prolonged hyporexia and partial IO in the 15 days prior to clinical examination. The finding of bilateral ovarian teratoma is also considered to be rare, since only the left ovary is usually affected (MACHADO et al., 2015). Ovarian teratomas present unique histological features, as tissues derived from more than one of the three germ layers are present, including neural tissue, adipose tissue, bone, teeth, and respiratory epithelium. There are several theories on the histogenesis of teratomas, but it is now believed that benign cystic ovarian teratomas are parthenogenetic tumors that develop from a single germ cell that had completed its first, but not its second meiotic division, causing gene disruption that triggers signaling defects in either oocytes or in the surrounding follicular granulosa cells (BALAKRISHNAN \& CHAILLET, 2013).

Ocular squamous cell carcinoma (OSCC) is the most common neoplasm in cattle around the world, accounting for important economic losses. Metastases are rare and are usually seen in animals with large tumors. In such cases, neoplastic cells initially reach the lymph nodes of the head before reaching the bloodstream via the thoracic duct. In addition to the regional lymph nodes, metastases have been observed in the lungs, heart, pleura, liver, and kidneys (TSUJITA \& PLUMMER, 2010). The case reported here represents a rare clinical presentation, since the primary tumors were small OSCC and/or vulval carcinomas. Besides the adrenal gland, metastases and tumor emboli in the lungs, kidneys, and spleen were also present, confirming the aggressiveness of the neoplasm. Digestive clinical signs are associated with the anatomical location of the tumor, since the ventral surface of the right kidney is associated with the liver, pancreas, duodenum, and colon. Therefore, the large mass in the adrenal gland caused compression of the descending duodenum and thus partial IO. The strong cytoplasmic immune labeling of tumor cells with chromogranin A confirmed these gross and histological findings.

In conclusion, ovarian teratoma and metastatic adrenal carcinoma are two unusual causes of IO in cattle. Practitioners should take care to include these abdominal tumors in the differential diagnosis of cattle with clinical signs of partial or total non-strangulated IO.

\section{ACKNOWLEDGEMENT}

To the Pró-Reitoria de Pesquisa, Universidade Federal de Minas Gerais (UFMG) for the English editing of this article.

\section{REFERENCES}

BALAKRISHNAN, A.; CHAILLET, R.J. Role of the inositol polyphosphate-4-phosphatase type II Inpp4b in the generation of ovarian teratomas. Developmental Biology, v.373, n.1, p.118-129, 2013. Available from: <http://dx.doi.org/10.1016/j. ydbio.2012.10.011>. Accessed: Nov. 1, 2015. doi: 10.1016/j. ydbio.2012.10.011.

CÂMARA, A.C.L. et al. Primary abomasal impaction in 14 cattle from Pernambuco State, northeastern Brazil. Pesquisa Veterinária Brasileira, v.29, n.5, p.387-394, 2009. Available from: <http:// dx.doi.org/10.1590/S0100-736X2009000500005>. Accessed: Nov. 1, 2015. doi: 10.1590/S0100-736X2009000500005.

GROSSI, A.B. et al. Histologic and immunohistochemical classification of 41 bovine adrenal gland neoplasms. Veterinary Pathology, v.50, n.3, p.534-542, 2013. Available from: <http:// dx.doi.org/10.1177/0300985812469638>. Accessed: Nov. 1, 2015. doi: $10.1177 / 0300985812469638$.

MACHADO, C.C. et al. Occurrence of bilateral ovarian teratoma in buffalo - case report. Archives of Veterinary Science, v.20, n.1, p.31-36, 2015. Available from: <http://ojs.c3sl.ufpr.br/ojs2/index. php/veterinary/article/view/41125/26026>. Accessed: Nov. 1, 2015.

SCHLAFER, D.H.; MILLER, R.B. Female genital system. In: MAXIE, M.G. Jubb, Kennedy, and Palmer's pathology of domestic animals. 5.ed. New York: Elsevier Saunders, 2007. V.3, p.429-564.

TSUJITA, H.; PLUMMER, C.E. Bovine ocular squamous cell carcinoma. Veterinary Clinics of North America, Food Animal Practice, v.26, n.3, p.511-529, 2010. Available from: <http:// dx.doi.org/10.1016/j.cvfa.2010.08.003>. Accessed: Nov. 1, 2015. doi: $10.1016 /$ j.cvfa.2010.08.003.

VAN METRE, D.C. et al. Abdominal emergences in cattle. Veterinary Clinics of North America, Food Animal Practice, v.21, n.3, p.655-696, 2005. Available from: <http://dx.doi. org/10.1016/j.cvfa.2005.06.003>. Accessed: Nov. 1, 2015. doi: 10.1016/j.cvfa.2005.06.003. 